\title{
PROFIL PENDIDIKAN DI KAWASAN LORONG: STUDI KASUS DI KECAMATAN TAMALATE KOTA MAKASSAR
}

\author{
Bastiana \\ Jurusan Pendidikan Luar Biasa FIP UNM \\ bastiana@unm.ac.id
}

\begin{abstract}
Abstrak
Survey tentang 'Profil Lorong Kota Makassar' (2015) menunjukkan bahwa Kecamatan Tamalate memiliki 1.491 Lorong (jalur atau jalan kecil), jumlah terbesar di antara 14 kecamatan di Kota Makassar dan tersebar dalam 11 kelurahan. Survei menemukan berbagai karakteristik Lorong, Salah satunya adalah profil pendidikan. Fenomena pendidikan di Lorong menggambarkan jumlah Lorong dengan tingkat pendidikan penduduk dan tingkat lembaga pendidikan yang tersedia. Responden dalam penelitian ini adalah Lorong. Setiap Lorong diprofilkan dengan tingkat pendidikan penduduk yang tinggal serta tingkat lembaga pendidikan yang ada. Hasil survei menunjukkan bahwa (1) 62,0\% Lorong berpenduduk lulusan tingkat SMA, 19,1\% Lorong berpenduduk lulusan pendidikan tinggi, dan 12,3\% lulusan SMP, tidak berpendidikan hanya ditemukan di 6,6\% Lorong; (2) semua tingkat lembaga pendidikan yang ditemukan di Lorong tetapi dalam jumlah yang berbeda; jumlah terbesar adalah Taman Kanak-Kanak, diikuti oleh SD kemudian sekolah menengah (SMP dan SMA) dan yang paling sedikit adalah perguruan tinggi. Disimpulkan bahwa lorong di Kecamatan Tamalate sebagian besar ditempati oleh mereka yang berpendidikan pada tingkat menengah. Namun, profil pendidikan Lorong dapat digunakan sebagai data bagi pemerintah Kota Makassar dalam merumuskan program pembangunan sosial dan ekonomi, dalam memberdayakan Lorong sebagai bagian dari Kota dunia sebagaimana dimaksud oleh otoritas saat ini.
\end{abstract}

Kata Kunci: Lorong, Pendidikan

\begin{abstract}
A survey on 'Profil Lorong Kota Makassar' (2015) shows that Tamalate Sub-District (Kecamatan Tamalate) has 1491 lorong (pathways or small roads), the biggest number among the 14 sub-districts in the City of Makassar and spreading in 11 villages (Kelurahan) in the Kecamatan. The survey mentioned above found a variety of lorong characteristics, One of them is the educational profile of the site. The fenomena of education in lorong describes number of lorong with level of education of people and level of educational institution available in the area. The respondent in the study was lorong. Each lorong was profiled with level of education of people staying in as well as level of educational institution located in the area. The survey result indicates that (1) 62,0\% lorong occupied by people graduated krom secondary level (SMA), 19,1\% lorong
\end{abstract}


occupied by people graduated from higher education, and 12,3\% graduated from SMP level, uneducated people only found in 6,6\% lorong; (2) all level of educational institution are found in the lorong but in different number; the biggest number is Kindergarden (Taman Kanak-Kanak), followed by primary school (Sekolah Dasar) then secondary school (SMP and SMA) and the least is higher education. It can be concluded that lorongs in the Kecamatan Tamalate are mostly occupied by Well educated people though only at middle level. However, the educational profile of the lorong could be of some useful data for city government of Makassar in formulating social and economic development programs, perticularly in empowering the lorong as part of world City as intended by current authority.

Key words: lorong, Education

\section{PENDAHULUAN}

Sesuai dengan Rencana Pembangunan Jangka Panjang Menengah Daerah (RPJMD) Kota Makassar dalam salah satu misinya Merestorasi Tata ruang menjadi Tata Ruang Kota Standar Dunia. Standar kota dunia yang diinginkan adalah kota yang nyaman dan aman untuk semua. Untuk mewujutkan kota dunia, Walikota Makassar, Muhammad Ramadhan Pomanto, melakukan upaya melalui Restorasi Lorong. Memaparkan konsep lorongnya dihadapan Lemhanas dengan judul Restorasi Lorong di Kota Makassar Guna Menciptakan Keamanan, Kenyamanan, Kesejahteraan Dalam Rangka Ketahanan Nasional. Menurutnya, lorong adalah ibarat sel kota dan otaknya adalah pemerintah." Sel dan otak menjadi penentu apakah kota itu bisa terus hidup, sehat atau bahkan mati,"

Untuk mewujudkan konsep restorasi lorong, salah satu langkah nyata yang dilakukan adalah mengadakan survey tentang Profil Lorong Kota Makassar. Survey bertujuan untuk menyediakan database profil pisik, dan kehidupan sosial di setiap lorong Kota Makassar. Untuk memudahkan survey, dilakukan pembagian wilayah survey berdasarkan kecamatan.

Kecamatan Tamalate merupakan salah satu kecamatan diantara 14 kecamatan yang ada di Kota Makassar. Merupakan Kecamatan yang memiliki jumlah lorong terbanyak diantara kecamatan lain di Kota Makassar. Data hasil survey menunjukkan bahwa jumlah lorong di kecamatan Tamalate adalah 1491 atau 22,2 \% dari jumlah lorong yang ada di Kota Makassar. Lorong-lorong tersebut tersebar ke dalam 11 kelurahan.

Berbicara tentang lorong, maka akan ditemukan berbagai karakteristik baik dari segi fisik maupun dari sosial ekonomi yang mewarnai dinamika kehidupan lorong. Salah satu karakteristik yang berpengaruh dalam dinamika lorong adalah pendidikan. Penelitian ini bertujuan untuk menjelaskan profil lorong di Kecamatan Tamalate berdasarkan tingkat pendidikan penduduknya serta melihat lorong berdasarkan lembaga pendidikan di setiap lorong.

\section{TINJAUAN PUSTAKA}

a. Pengertian lorong

Tidak mudah menelusuri pengertian lorong yang sesungguhnya apalagi yang bersumber dari literatur dan jurnal. Bahkan dalam Peraturan Pemerintah Republik Indonesia Nomor 34 Tahun 2006 Tentang Jalan dan Pedoman Standar Pelayanan Minimal Pedoman Penentuan Standar Pelayanan Minimal Bidang Penataan Ruang, 
Perumahan dan Permukiman dan Pekerjaan Umum (Keputusan Menteri Permukiman dan Prasarana Wilayah No. 534/KPTS/M/2001) tidak dikenal lorong, yang dikenal adalah jalan lingkungan dan jalan setapak. Namun demikian, kebutuhan akan pemahaman tentang lorong harus diperoleh untuk menjadi landasan teori yang dijadikan dasar dari penelitian ini.

Menurut sejarahnya, pada awalnya lorong atau jalan setapak adalah jejak-jejak manusia yang melakukan perpindahan dari satu tempat ke tempat lain secara musiman atau apabila persediaan makanan dan minuman di tempat itu tidak tersedia lagi (Abadi; 2010). Pada saat kehidupan berkelompok manusia meningkat secara kuantitas, seiring dengan berkembangnya tingkat keberadaban manusia, maka terbentuklah suku-suku atau bangsa-bangsa. Mereka mulai menggunakan jalan yang tadinya hanya terbentuk secara musiman menjadi 'permanen' untuk melakukan hubungan antarsuku/bangsa, baik hubungan sosial maupun ekonomis, berupa barter barang-barang kebutuhan hidup.

Mengacu pada PP no. 34 tahun 2006 dan Kepmen no 534 tahun 2001, bahwa jalan lingkungan mempunyai spesifikasi panjang 40 -60 meter dan lebar $2-5$ meter. Sedangkan jalan setapak mempunyai panjang 50-110 meter dan lebar 0,8-2 meter. Lorong yang dimaksud dalam penelitian ini adalah jalan tetapi tidak mempunyai nama jalan yang diberikan secara resmi dan merupakan cabang dari jalan utama. Tidak ada spesifikasi khusus berapa panjang dan lebar yang ditetapkan.

Lorong dibagi dalam 3 klasifikasi yaitu lorong utama, lorong cabang dan lorong ranting. Lorong utama adalah lorong yang berhubungan langsung dengan jalan utama. Lorong cabang adalah lorong yang berhubungan dengan lorong utama. Lorong ranting adalah lorong yang berhubungan dengan lorong cabang.

b. Lembaga Pendidikan dan Tingkat pendidikan masyarakat di lorong

Pendidikan adalah usaha yang dilakukan untuk memperoleh pengetahuan, sikap dan keterampilan. Proses pendidikan mempunyai tingkatan-tingkatan tertentu yang harus diselesaikan yang menjadi simbol tentang level seseorang individu telah menguasai atau menyelesaikan tingkatan pendidikan tertentu. Menurut UU RI No. 20 tahun 2003 pasal 14 tentang sistem pendidikan nasional dijelaskan bahwa jenjang atau tingkatan pendidikan formal terdiri atas pendidikan dasar, pendidikan menengah, dan pendidikan tinggi.

1) Pendidikan Dasar Pada Pasal 17 dijelaskan bahwa Pendidikan dasar merupakan jenjang pendidikan yang melandasi jenjang pendidikan menengah. Pendidikan dasar berbentuk Sekolah Dasar (SD) dan Madrasah Ibtidaiyah (MI) atau bentuk lain yang sederajat serta Sekolah Menengah Pertama (SMP) dan Madrasah Tsanawiyah (MTs), atau bentuk lain yang sederajat.

2) Pendidikan Menengah Pendidikan menengah merupakan lanjutan pendidikan dasar. Pendidikan menengah terdiri atas pendidikan menengah umum dan pendidikan menengah kejuruan. Pendidikan menengah berbentuk Sekolah Menengah Atas (SMA), Madrasah Aliyah (MA), Sekolah Menengah Kejuruan (SMK), dan Madrasah Aliyah Kejuruan (MAK), atau bentuk lain yang sederajat.

3) Pendidikan Tinggi Pendidikan tinggi merupakan jenjang pendidikan setelah pendidikan menengah yang mencakup program pendidikan diploma, sarjana, magister, spesialis, dan doktor yang diselenggarakan oleh pendidikan tinggi. Pendidikan tinggi diselenggarakan dengan sistem terbuka.

Fungsi tiap lembaga pendidikan tergantung pada jenis lembaga pendidikannya. Namun secara umum, fungsi lembaga pendidikan seperti yang 
dijelaskan oleh Murdiyatmoko (2004) antara lain memberikan persiapan perananperanan pekerjaan, sebagai perantara perpindahan warisan kebudayaan, memperkenalkan tentang berbagai peranan, memberikan landasan bagi penilaian dan pemahaman status relatif, dan memperkuat penyesuaian diri. Dimanapun lembaga pendidikan itu berada, akan melaksanakan fungsi tersebut. Terlebih jika lembaga pendidikan itu berada di lorong akan memperkuat tatanan lorong tersebut.

Tingkat pendidikan yang dimaksud dalam penelitian ini tetap mengacu kepada UU RI No. 20 tahun 2003 pasal 14. Namun demikian, pengelompokan masyarakat lorong berdasarkan tingkat pendidikan juga ditambahkan dengan kelompok tidak tamat SD. Penambahan kelompok ini, didasarkan pada survey awal bahwa masih banyak penduduk di lorong yang tidak memiliki ijazah.

\section{c. METODE PENELITIAN}

Metode penelitian adalah kualitatif, mendeskripsikan profil lorong berdasarkan tingkat pendidikan penduduk dan lembaga pendidikan yang ada pada setiap lorong. Unit analisis adalah lorong yang ada di Kecamatan Tamalate. Jumlah lorong yang ada di Kecamatan Tamalate berdasarkan survey Profil Lorong Kota Makassar Tahun 2015 adalah 1924 lorong. Teknik pengumpulan data yang digunakan adalah teknik angket dan wawancara kepada tokoh masyarakat dan penduduk lorong, alat pengumpul data adalah daftar angket dan pedoman wawancara. Teknik analisis data yang digunakan adalah teknik analisis deskriptif.

\section{d. TEMUAN DAN PEMBAHASAN}

Kecamatan Tamalate merupakan salah satu kecamatan dari 14 kecamatan yang ada di Kota Makassar. Berada di bagian selatan kota Makassar dengan batasan di sebelah utara dengan Kecamatan Mamajang, di sebelah timur Kabupaten Gowa, di sebelah selatan Kabupaten Takalar dan di sebelah barat dengan Selat Makassar. Saat ini terdapat 11 kelurahan. Letak masing-masing kelurahan ke ibukota kecamatan bervariasi antara 1-2 km (Maccini Sombala dan Balang Baru), antara 3-4 km (Jongaya dan Parang Tambung), kelurahan lainnya berjarak 5-10 km. Menurut data statistik tahun 2013, Kelurahan Barombong memiliki wilayah terluas yaitu 7,34 km, terluas kedua adalah kelurahan Tanjung Merdeka dengan luas wilayah 3,37 km, sedangkan yang paling kecil luas wilayahnya adalah kelurahan Bungaya yaitu $0,29 \mathrm{~km}$.

Merupakan kecamatan yang memiliki lorong terbanyak diantara kecamatan yang ada di Kota Makassar, yaitu 1491 lorong yang terbagi dalam klasifikasi lorong utama, lorong cabang dan lorong ranting. Pembagian jumlah lorong dapat dilihat pada grafik di bawah ini. 


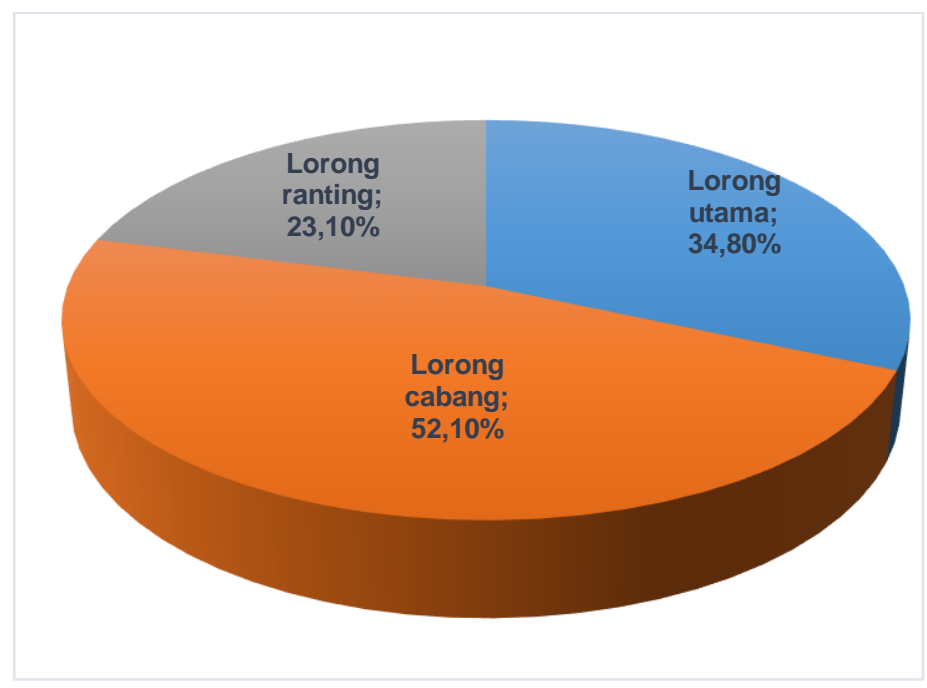

Gambar 1. Klasifikasi lorong di kecamatan Tamalate

Data gambar 1 menunjukkan bahwa jumlah lorong cabang lebih besar dari lorong utama dan lorong ranting. Ini berarti bahwa penyebaran penduduk yang semakin tinggi menuntut akses yang lebih mudah untuk melakukan mobilisasi sehingga membutuhkan lorong cabang yang lebih banyak. Walaupun tidak hanya sampai disitu, pada perkembangan selanjutnya ternyata masyarakat juga membutuhkan lorong ranting untuk akses mereka yang tidak dapat menjangkau lorong cabang. Perkembangan jalan atau lorong menurut Abadi, pada awalnya hanya satu dua orang yang melalui tetapi ketika itu memudahkan dalam melakukan mobilitas ke berbagai tujuan, akhirnya menjadi permanen (Abadi; 2010). Keberadaan lorong dimaksudkan untuk memfasilitasi akses masyarakat untuk memperluas jaringan, meningkatkan kelangsungan sistem ruang terbuka dan menjadi sarana berolahraga dan rekreasi bagi masyarakat setempat Dinamika sosial lorong semakin berkembang seiring perubahan dan pertambahan penduduk dalam lorong.

Keberadaan lorong tidak hanya sebagai jalan menuju dan ke berbagai tujuan, tetapi juga berperan penting dalam pertumbuhan dan perkembangan penduduk di sekitarnya. Lorong dapat juga berfungsi menjadi berbagai fasilitas seperti tempat pagelaran pesta perkawinan, menjadi lapangan olah raga, dan tempat hiburan lainnya. Begitu pentingnya lorong bagi sebuah kota, seperti paparan Pomanto (2016) bahwa lorong adalah sel kota, membangun lorong sama pentingnya dengan membangun kota dunia. Demikian pula Walsh (2002) melihat bahwa lorong merupakan komponen infrastruktur penting dari ruang terbuka kota.

Sarana pendidikan di Kecamatan Tamalate telah tersedia mulai dari tingkat Taman kanak-kanak sampai perguruan tinggi. Kajian tingkat pendidikan masyarakat di kecamatan Tamalate ditinjau berdasarkan lorong. Data tentang tingkat pendidikan masyarakat pada setiap lorong di kecamatan Tamalate dapat dilihat pada grafik 2 berikut: 


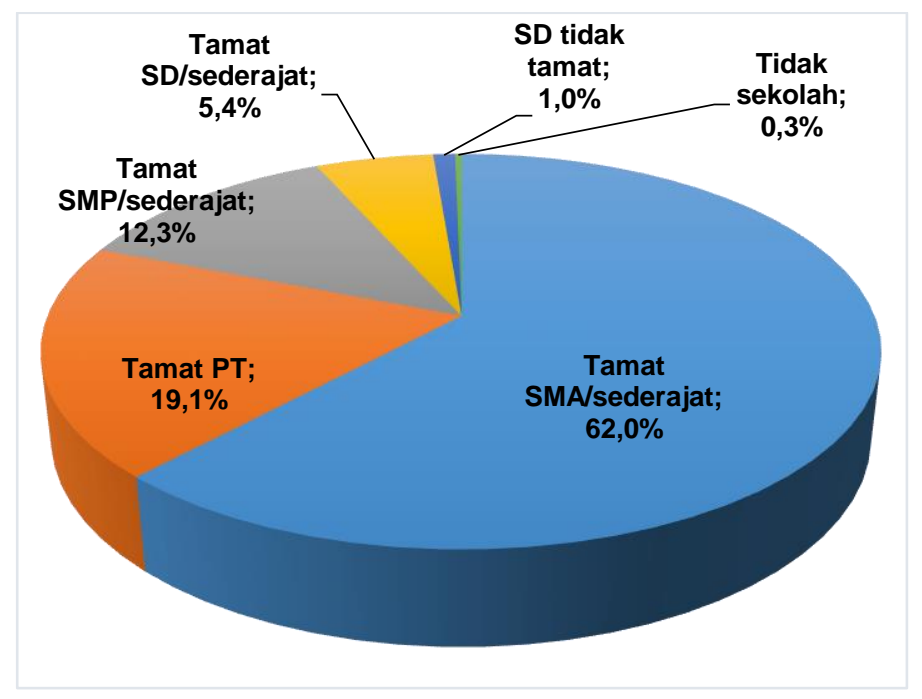

Gambar 2: Jumlah lorong dengan tingkat pendidikan penduduk

Gambar 2 menunjukkan bahwa dari 1491 jumlah lorong sebagian besar lorong atau $62,0 \%$ lorong memiliki penduduk rata-rata tingkat pendidikannya tamat SMA/sederajat diikuti oleh lorong yang dominan tamat perguruan tinggi dan selanjutnya adalah tamat SMP/sederajat. Presentasi lorong yang tingkat pendidikan penduduknya tamat SMA/sederajat lebih besar dibanding dengan tingkat pendidikan perguruan tinggi. Bahkan masih ada lorong 1,3\% yang memiliki penduduk dominan tidak mempunyai ijazah, artinya tidak tamat SD dan tidak bersekolah. Mencermati data ini, dapat disimpulkan bahwa rata-rata penduduk lorong di kecamatan Tamalate hanya memiliki ijazah SMA/sederajat. Terdapat 1,3\% lorong yang rata-rata penduduknya tidak memiliki ijazah.

Tingkat pendidikan merupakan faktor yang sangat penting dalam masyarakat karena akan berhubungan dengan berbagai aspek kehidupan terutama pada jenis pekerjaan dan tingkat pendapatan. Beberapa penelitian menemukan pengaruh tingkat pendidikan dalam aspek tersebut. Tarigan (2006) dalam kesimpulannya mengatakan bahwa tingkat pendidikan berpengaruh pada jenis pekerjaan kalau pekerjaan tersebut berjenjang, tetapi kalau pekerjaan tersebut seragam maka tidak ada pengaruh tingkat pendidikan.

Selain data tentang lorong dengan tingkat pendidikan penghuninya, kajian lorong tentang pendidikan juga dilihat berdasarkan lembaga pendidikan yang ada di setiap lorong kecamatan Tamalate. Data tentang lembaga pendidikan yang ada di setiap lorong kecamatan Tamalate dapat dilihat pada Grafik 3 di bawah ini: 


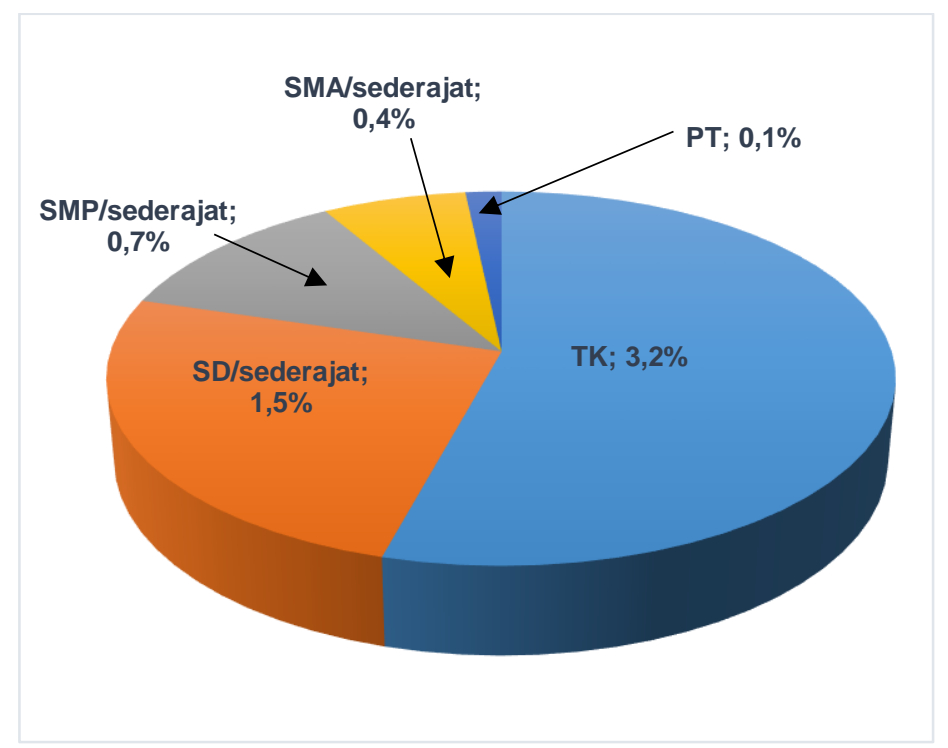

Gambar 3: Jumlah lorong dengan lembaga pendidikan

Gambar 3 menunjukkan bahwa ada 3,2\% lorong yang mempunyai lembaga pendidikan Tamak Kanak-kanak (TK) dan lembaga inilah yang terbanyak dimiliki oleh lorong di kecamatan Tamalate. Selanjutnya terdapat 1,5\% lorong yang memiliki lembaga pendidikan tingkat SD/sederajat. Hanya ada $0,1 \%$ lorong yang memiliki perguruan tinggi. Jika data lorong yang memiliki lembaga pendidikan dijumlahkan berarti hanya ada 45 lorong atau 5,9\% lorong yang memiliki lembaga pendidikan. Jumlah yang sangat kecil dibanding dengan banyaknya lorong yang ada di kecaman Tamalate.

Ada dua kemungkinan yang dapat dilihat dari jumlah lembaga pendidikan di lorong di kecamatan Tamalate. Pertama, lembaga pendidikan menyebar pada jalan utama bukan pada lorong. Kedua, jumlah lembaga pendidikan memang tergolong sedikit. Data statistik tahun 2013 menemukan bahwa lembaga pendidikan yang terdapat di kecamatan Tamalate tersebut meliputi 25 taman kanak-kanak, 41 SD, 14 SMP, dan 11 SMA serta 2 perguruan tinggi.

Jumlah lembaga pendidikan di Kecamatan Tamalate cukup memadai, hanya saja tidak berada di lorong tetapi menyebar di jalan-jalan utama. Banyak pertimbangan mengapa lembaga pendidikan lebih banyak di jalan utama. Pertimbangan utama adalah bahwa lembaga pendidikan yang berada di jalan utama mudah dijangkau dengan transportasi, lebih mudah terlihat lokasinya dibanding jika lembaga pendidikan berada di lorong. Kecuali untuk tingkat TK karena jangkauan dari lembaga ini tidak luas, hanya disekitar lokasi keberadaan sekolah. Namun demikian, keberadaan lembaga pendidikan di lorong dapat menjadi variabel peningkatan keamanan dan ketertiban lorong. Untuk itu, perlu diupayakan banyaknya lorong yang memiliki lembaga pendidikan.

\section{e. KESIMPULAN}

Berdasarkan hasil dan pembahasan terhadap data penelitian maka dapat disimpulkan bahwa lorong di Kecamatan Tamalate sebagian besar ditempati oleh mereka yang berpendidikan pada tingkat menengah. Untuk lembaga pendidikan, masih 
kurang lorong yang memiliki lembaga pendidikan dibanding dengan besarnya jumlah lorong yang ada di Kecamatan Tamalate. Kepada pemerintah Kota Makassar yang menggalakkan pemberdayaan masyarakat lorong, perlunya penyuluhan akan pentingnya pendidikan pada lorong-lorong yang rata-rata tingkat pendidikan penduduknya berada pada tingkat menengah ke bawah. Tujuannya agar penduduk lorong dapat berdaya dalam meningkatkan kualitas hidupnya. Selain itu, perlu lembaga pendidikan menyentuh lorong. Kehadiran lembaga pendidikan pada lorong dapat memotivasi penduduk untuk meningkatkan pendidikannya ke jenjang yang lebih tinggi. Lorong yang penduduknya memiliki tingkat pendidikan yang lebih tinggi dapat diprediksi menjadi lorong yang aman, nyaman, dan produktif.

Profil pendidikan Lorong pada penelitian ini dapat digunakan sebagai data bagi pemerintah Kota Makassar dalam merumuskan program pembangunan sosial dan ekonomi, dalam memberdayakan Lorong sebagai bagian dari Kota dunia sebagaimana dimaksud oleh otoritas saat ini.

\section{DAFTAR PUSTAKA}

Abadi, Khoirul. 2010. Pengajaran Perencanaan Geometrik Jalan http://khoirulabadi.staff.umm.ac.id/files/2010/09/B-1-26Pendahuluan.pdf

Ottawa Citycouncil. 2012. Park And Pathway Development Manual (http://ottawa.ca/calendar/ottawa/citycouncil/occ/2012/03-28/pec/9\%20 \%20Park \% 20and\%20Pathway\%20Manual.pdf).

Menteri Permukiman dan Prasarana Wilayah. 2001. Pedoman Standar Pelayanan Minimal Pedoman Penentuan Standar Pelayanan Minimal Bidang Penataan Ruang, Perumahan dan Permukiman dan Pekerjaan Umum (Keputusan Menteri Permukiman dan Prasarana Wilayah No. 534/KPTS/M/2001)

Peraturan Pemerintah Republik Indonesia Nomor 34 Tahun 2006 Tentang Jalan

Pomanto, Danny. 2016. Wali Kota Makassar Lauching 3M (Majurong 11, Maroasi, dan Maccarong) http://makassarkota.go.id/berita-1100-wali-kota-makassarlauching-3m-majurong-ll-maroasi-dan-maccarong.html.

Statistik daerah (statda) Kecamatan Tamalate . 2013. Badan Pusat Statistik. makassarkota.bps.go.id/data/publikasi/publikasi_25/.../searchtext.xml

Tarigan, Robinson. 2006. Pengaruh Tingkat Pendidikan Terhadap Tingkat Pendapatan Perbandingan Antara Empat Hasil Penelitian http://repository.usu.ac.id/bitstream/123456789/16004/1/was-feb2006$\% 20 \% 283 \% 29$.pdf

Walsh, Karl. 2002. Brampton's PathWays Master Plan Director of Community Design, Parks Planning and Development City of Brampton

Mursiyatmoko, Janu. 2004. Sosiologi Memahami dan Mengkaji Masyarakat. Jakarta; Grafondo Media Pratama. 
